\title{
Longterm endocrine effects of cancer
}

\author{
Margaret Zacharin \\ From 7th APPES Biennial Scientific Meeting \\ Nusa Dua, Bali. 14-17 November 2012
}

Survival after childhood cancer has increased over the last 25 years with around $80 \%$ overall survival but outlook is not trouble free. Within 25 years of diagnosis, $4 \%$ will have a second tumour. Cardiotoxicity from anthracyclines, radiation related health problems and endocrine deficiencies all contribute to increased mortality, with $18 \%$ reported to have died 30 years after diagnosis. Memory processing deficits after childhood cranial radiation result in additional burdens of intellectual, psychosocial and emotional disability.

Endocrine late effects of radiation and chemotherapy can be direct, resulting in hypofunction of endocrine glands or indirect resulting in metaplasia, cancer and altered bone growth. Deficiencies of hypothalamic pituitary hormones can be expected in $60-100 \%$ of patients by 8-10 years after radiation exposure.

Pubertal timing and tempo is altered by cranial radiation, with combinations of early puberty and growth hormone deficiency causing diagnostic and management confusion. Evolution of hormonal losses need be recognized.

Gonadal dysfunction occurs after both radiation and chemotherapy at any age. The prepubertal testis is not protected from effects of chemotherapy. Age at treatment, type and dose all predict outcome. Loss of function in germinal epithelium and Leydig cells is not reflected in gonadotrophin alterations until age 9-10 years. Abnormal timing of menarche in survivors of central nervous system tumours is common. Follicular reserve in young females after cancer treatment is reduced with high risk for premature menopause and little evidence that the ovary can be protected from insult, although $50 \%$ of children exposed to early radiation or chemotherapy retain sufficient gonadal function to initiate or complete puberty. Preservation of gonadal tissue prior to cancer treatment is now a priority, with semen storage, or gonadal biopsy being offered or considered in both sexes before exposure to gonadotoxins.

However, fertility recovery can occur and appropriate contraceptive needs must be met. Cerebral arteritis occurs after brain radiation, with early cerebrovascular accident. HRT may need to be tailored to reduce this risk.

Solid organ radiation exposure is hazardous. Thyroid cancer after radiation exposure occurs at 20 times population risk, with regular thyroid ultrasound every 2 years now recommended and FNA as required. Pelvic radiation results in poor pregnancy outcomes with increased foetal loss and small for dates infants. Bladder risks for cancer after cyclophosphamide, abdominal and pelvic radiation are worsened by smoking and alcohol. Bowel risks are currently unknown.

1 in 700 adults is now a survivor of childhood cancer and $60 \%$ have at least one chronic health problem. Ongoing surveillance is required to improve outcomes for this group of young people.

Published: 3 October 2013

\section{References}

1. de Ville de Goyet M, Moniotte S, Brichard B: Cardiotoxicity of Childhood Cancer Treatment: Update and Current Knowledge on Long-Term Follow-Up. Paediatr Oncol 2012.

2. Kenney LB, Cohen LE, Shnorhavorian M, Metzger ML, et al: Reproductive Health After Childhood, Adolescent, and Young Adult Cancers: A Report From the Children's Oncology Group. J Clin Oncol 2012.

3. Gurney JG, Krull KR, Kadan-Lottick N, et al: Social outcomes in the Childhood Cancer Survivor Study cohort. J Clin Oncol 27(14):2390-5.

4. Ergun-Longmire $B$, Mertens $A C$, Mitby $P$, et al: Growth hormone treatment and risk of second neoplasms in the childhood cancer survivor. $J$ Clin Endocrinol Metab 2006, 91(9):3494-8.

5. Ogilvy-Stuart AL, Clayton PE, Shalet SM: Cranial irradiation and early puberty. J Clin Endocrinol Metab 1994, 78(6):1282-6.

6. van Casteren N, van der Linden G, Hakvoort-Cammel F, et al: Effect of childhood Cancer on fertility markers in adult male long term survivors. Pediatr Blood Cancer 2009, 52:108-112.

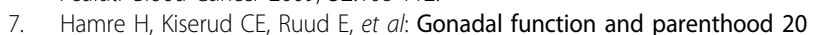
years after treatment for childhood lymphoma: A cross-sectional study. Pediatr Blood Cancer 2012, 59(2):271-7.

8. Signorello LB, Cohen SS, Bosetti C, Stovall M, Kasper CE, Weathers RE, Whitton JA, Green DM, Donaldson SS, Mertens AC, Robison LL, Boice JD Jr.: Female survivors of childhood cancer: preterm birth and low birth weight among their children. J Natl Cancer Inst 98(20):1453-61.

9. Bowers DC, Liu $Y$, Leisenring W, et al: Late-occurring stroke among longterm survivors of childhood leukemia and brain tumors: a report from the Childhood Cancer Survivor Study. J Clin Oncol 2006, 24(33):5277-82. 
10. Clanton NR, Klosky JL, Li C, Jain N, et al: Fatigue, vitality, sleep, and neurocognitive functioning in adult survivors of childhood Cancer: A report from the childhood cancer survivor study. Cancer 2011.

11. Crawshaw MA, Sloper P: Swimming against the tide- the influence of fertility matters on the transition to adulthood or survivorship following adolescent cancer. Eur J Cancer Care 2010, 19(5):610-20.

12. Armstrong $G$, Liu $Q$, Yasui $Y$, et al: Long-Term Outcomes Among Adult Survivors of Childhood Central Nervous System Malignancies inthe Childhood Cancer Survivor Study. J Natl Cancer Inst 2009, 101:946-958.

13. Keene D, Sajjad Y, Makin G, et al: Sperm Banking in the United Kingdom is Feasible in Patients13 Years Old or Older with Cancer. J Urol 2012, 188:594-597.

14. Patterson B, Wasilewski-Masker $K$, A, Ryerson AB, et al: Endocrine Health Problems Detected in 519 PatientsEvaluated in a Pediatric Cancer Survivor Program. J Clin Endocrinol Metab 2012, 97:810-818.

15. Taylor A, Croft A, Palace A, et al: Risk of thyroid cancer in survivors of childhood cancer: Results from theBritish Childhood Cancer Survivor Study. Int. J. Cancer 2009, 125:2400-2405.

doi:10.1186/1687-9856-2013-S1-018

Cite this article as: Zacharin: Longterm endocrine effects of cancer. International Journal of Pediatric Endocrinology 2013 2013(Suppl 1):018.

\section{Submit your next manuscript to BioMed Central} and take full advantage of:

- Convenient online submission

- Thorough peer review

- No space constraints or color figure charges

- Immediate publication on acceptance

- Inclusion in PubMed, CAS, Scopus and Google Scholar

- Research which is freely available for redistribution

Submit your manuscript at www.biomedcentral.com/submit
Biomed Central 